\title{
Resistance to the alkali-aggregate reaction of sustainable mortars produced with scheelite tailings in replacing natural sand aggregates
}

\author{
Resistência à reação álcali-agregado de argamassas sustentáveis produzidlas com rejeitos de \\ scheelita em substituição aos agregados de areia natural \\ Resistencia a la reacción álcali-agregado de morteros sostenibles producidos con relaves de
} scheelita para reemplazar los agregados naturales de arena

Received: 10/24/2021 | Reviewed: 11/01/2021 | Accept: 11/09/2021| Published: 11/14/2021

Brunna Lima de Almeida Victor Medeiros
ORCID: https://orcid.org/0000-0003-0474-0818
Instituto Federal de Educação, Ciência e Tecnologia da Paraíba, Brazil
E-mail: prof.brunna.almeida@gmail.com
Jucielle Veras Fernandes
ORCID: https://orcid.org/0000-0003-4487-6883
Universidade Federal de Campina Grande, Brazil
E-mail: jucielle_fernandes@hotmail.com
Fabiana Pereira da Costa
ORCID: https://orcid.org/0000-0002-0071-3014
Universidade Federal de Campina Grande, Brazil
E-mail: fabiana.costa@estudante.ufcg.edu.br
Sâmea Valensca Alves Barros
ORCID: https://orcid.org/0000-0002-9035-486X
Universidade Federal Rural do Semi-Árido, Brazil
E-mail: sameavalensca@ufersa.edu.br
Alisson Mendes Rodrigues
ORCID: https://orcid.org/0000-0003-0449-9219
Universidade Federal de Campina Grandes, Brazil
E-mail: alisson.mendes@professor.ufcg.edu.br
Gelmires de Araújo Neves
ORCID: https://orcid.org/0000-0002-2900-1600
Universidade Federal de Campina Grande, Brazil
E-mail: gelmires.neves@ufcg.edu.br

\begin{abstract}
This work produced coating mortars with scheelite tailings (ST) in total replacement of natural sand aggregate. The chemical and mineralogical composition of the scheelite tailings was determined by X-ray diffraction (XRD) and X-ray fluorescence (XRF). Mortar samples with a mass proportion of 1:2:9 (cement: lime: sand/scheelite tailings) were prepared with and without the scheelite tailings. The mortars were evaluated by mercury intrusion porosimetry and compressive and flexural strength tests. The resistance to the alkali-aggregate reaction was assessed from the bar expansion test and by scanning electron microscopy (SEM) in the crack and pore regions. The results indicate that until the 22nd day, the scheelite tailings were not reactive; however, in 28 days, the expansion was deleterious. SEM images did not detect the presence of amorphous alkaline gel characteristic of the alkali-aggregate reaction. Therefore, although the mortar with scheelite tailings aggregate has shown the deleterious potential to 28 days, mechanical tests indicate that it has the potential to be used as a coating mortar.
\end{abstract}

Keywords: Scheelite tailings; Alternative aggregate; Coating mortar; Alkali-aggregate reaction.

\section{Resumo}

Neste trabalho, argamassas de revestimento foram produzidas com rejeitos de scheelita (RS) em substituição total ao agregado de areia natural. A composição química e mineralógica do rejeito de scheelita foi determinada por difração de raios-X (DRX) e fluorescência de raios-X (FRX). Amostras de argamassa com proporção em massa de 1:2:9 (cimento: cal: areia/rejeito de scheelita) foram preparadas com e sem o rejeito de scheelita. As argamassas foram avaliadas por porosimetria de intrusão de mercúrio e testes de resistência a compressão e a flexão. A resistência a reação álcaliagregado foi avaliada a partir do teste de expansão de barra e por microscopia eletrônica de varredura (MEV) nas regiões de trincas e poros. Os resultados indicam que até o $22^{\circ}$ dia os rejeitos de scheelita não são reativos, no entanto, em 28 dias, a expansão foi deletéria. As imagens de MEV não constataram a presença de gel alcalino amorfo característico da reação álcali-agregado. Portanto, apesar da argamassa com agregado de rejeito de scheelita ter apresentado potencial 
deletério acima de 28 dias, os testes mecânicos indicam que ela possui potencial para ser utilizada como argamassa de revestimento.

Palavras-chave: Rejeito de scheelita; Agregado alternativo; Argamassa de revestimento; Reação álcali-agregado.

\section{Resumen}

En este trabajo, se produjeron morteros de revestimiento con relaves de scheelita (ST) en reemplazo total del agregado de arena natural. La composición química y mineralógica de los relaves de scheelita se determinó mediante difracción de rayos X (DRX) y fluorescencia de rayos X (FRX). Se prepararon muestras de mortero con una relación de masa de 1: 2: 9 (cemento: cal: arena / relaves de scheelita) con y sin los relaves de scheelita. Los morteros fueron evaluados mediante porosimetría de intrusión de mercurio y pruebas de resistencia a la compresión y flexión. La resistencia a la reacción álcali-agregado se evaluó a partir de la prueba de expansión y mediante microscopía electrónica de barrido (SEM) en las regiones de grietas y poros. Los resultados indican que hasta el día 22 los relaves de scheelita no son reactivos, sin embargo, en 28 días, la expansión fue deletérea. Las imágenes SEM no detectaron la presencia de gel alcalino amorfo característico de la reacción álcali-agregado. Por lo tanto, aunque el mortero con relaves de scheelita ha mostrado un potencial deletéreo durante a los 28 días, las pruebas mecánicas indican que tiene potencial para ser utilizado como mortero de revestimiento.

Palabras clave: Relaves de Scheelita; Agregado alternativo; Mortero de revestimiento; Reacción álcali-agregado.

\section{Introduction}

In recent decades, the global concern with preserving natural resources has intensified due to the growing market demand and the possibility of depletion of these resources originating from non-renewable sources (Yang et al., 2020). The civil construction sector stands out as one of the main responsible for the excessive consumption of natural resources. On the other hand, this sector can absorb the most diverse types of waste as an alternative raw material. Materials produced from waste, in addition to contributing to the reduction in the extraction of natural raw materials, also contribute to waste management, which is one of the main problems faced by industries and mining companies (Choi \& Choi, 2015).

As a result, several researches have been focused on developing sustainable materials, using alternative raw materials from mining tailings and industrial waste. Matias et al. (Matias et al., 2020) incorporated glass, cork, and rubber wastes in the production of mortars for plastering and obtained promising results. The authors evaluated the mortars for physical and mechanical behavior. Alekseev et al. (Alekseev et al., 2019) produced new ecological ceramic materials from red mud, hazardous bauxite waste, and foundry sand to replace sand-clay. The authors achieved mechanical strength results of $10.54 \mathrm{MPa}$ and water absorption between 2.77 and $14.41 \%$. Coppio et al. (Coppio et al., 2019) analyzed the incorporation of foundry sand generated in landfills as fine aggregate in Portland cement concrete. The results varied according to the characteristic of the tailings. Other authors (Almeida et al., 2021; Hoppe Filho et al., 2021; Huseien et al., 2018; Pereira-De-Oliveira et al., 2012; Samadi et al., 2020; Torres et al., 2020) used red ceramic wastes to be used as a partial replacement for Portland cement or as aggregates. However, studies on incorporating scheelite used as total aggregate in the mortar are not common in the literature. Other researchers (Almeida et al., 2021; Fernandes et al., 2020; Figueirêdo et al., 2020) used scheelite tailings to partially replace Portland cement or aggregate for the development of sustainable materials.

Scheelite is a calcium tungstate mineral $\left(\mathrm{CaWO}_{4}\right)$ mined to obtain tungsten, a chemical element with high thermal and electrical properties and excellent corrosion resistance, used in high value-added applications. However, while exploring the scheelite mineral, large amounts of tailings are generated, as only $1 \%$ of the extracted material is converted into tungsten tungsten (Souza et al., 2021). These tailings are accumulated in piles or deposition basins exposed to wind and rainwater. According to the Brazilian Mineral Summary, in 2017, Brazil produced approximately 593 tons, representing only $0.62 \%$ of all world production (Medeiros et al., 2021). In addition to causing accumulations in mining companies, these tailings lead to environmental contamination such as global warming, terrestrial acidification, and freshwater eutrophication (Furberg et al., 2019). 
Although several studies have already reported using scheelite as an alternative raw material, it is rare to find in the literature studies that used scheelite as a total replacement for natural sand aggregates in mortars. Furthermore, the behavior in relation to the alkali-aggregate reaction of mortars containing scheelite tailings has not yet been reported.

Alkali Aggregate Reaction (AAR) is a complex chemical process that occurs between cement alkalis $\left(\mathrm{Na}_{2} \mathrm{O}\right.$ and $\left.\mathrm{K}_{2} \mathrm{O}\right)$ and some mineral compounds present in specific aggregates. This process affects the durability of mortars and concretes because during AAR a highly expansive alkaline gel is generated, causing micro-cracks and cracks in the material (De Grazia et al., 2021). Some studies on cementitious materials based on ordinary Portland cement (OPC) state that the alkali-aggregate reaction also requires the presence of $\mathrm{Ca}^{+2}$. This process can occur through two main mechanisms: alkali-silica reaction (ASR) and alkalicarbonate reaction (ACR), with the most common ASR being (Barros et al., 2016; Munhoz et al., 2021).

Therefore, the objective of this work was to evaluate the feasibility of the total replacement of natural sand aggregate by scheelite tailings in the composition of coating mortars and investigate the resistance to alkali-aggregate reaction. Compressive and flexural strength tests evaluated the mechanical properties of sustainable mortars.

\section{Methodology}

\subsection{Raw Materials}

The materials used were: scheelite tailings (ST) collected from industrial complex Mineração Tomaz Salustiano S.A. located in the city of Currais Novos -RN, Brazil; Portland cement type CP-V from the company Cimento Nacional, located in the city of Pitimbu - PB, Brazil; hydrated lime (calcium hydroxide) of class CH-I from the company Carbomil SA, (Limoeiro do Norte - CE, Brazil); and sand provided by the Institute of Technological Research (IPT) (Butantã, São Paulo, Brazil) used to make the reference samples.

\subsection{Characterization of scheelite tailings}

The particle size distribution of the scheelite tailings and the sand was determined by the sieving method. For this was using sieves with different openings $(4.8 \mathrm{~mm}, 2.4 \mathrm{~mm}, 1.2 \mathrm{~mm}, 0.6 \mathrm{~mm}, 0.3 \mathrm{~mm}$, and $0.15 \mathrm{~mm})$. The specific mass and unit mass were obtained according to the ASTM C128 (“ASTM C128-15, Standard Test Method for Relative Density (Specific Gravity) and Absorption of Fine Aggregate,” 2015) and ASTM C29 (“ASTM C29 / C29M-17a, Standard Test Method for Bulk Density ('Unit Weight') and Voids in Aggregate," 2017) standards.

The chemical composition of scheelite tailings was determined by X-ray fluorescence (EDX-720 Shimadzu) and the mineralogical composition by X-ray diffraction (XRD) (XRD-6000 Shimadzu) with Cu-Ka radiation, goniometer speed of $2^{\circ} \cdot \mathrm{min}^{-1}, 0.02^{\circ}$ of step and $2 \theta$ angle range $10^{\circ}-70^{\circ}$. The morphology of the tailings grain was evaluated by Scanning Electron Microscopy (SEM).

\subsection{Preparation and characterization of the mortar samples}

Samples of mortar with a mass proportion of 1:2:9 (cement: lime: sand) without tailings and with tailings (cement: lime: scheelite tailings) were prepared. The water was added to the mortar mixtures until get the consistency index of $260 \pm 10 \mathrm{~mm}$, following ASTM C1437 (“ASTM C1437-20, Standard Test Method for Flow of Hydraulic Cement Mortar,” 2020). The samples were molded in prismatic molds with dimensions of $40 \mathrm{~mm} \times 40 \mathrm{~mm} \times 160 \mathrm{~mm}$. After 48 hours, the samples were demolded and cured in a humid chamber (temperature of $\sim 23^{\circ} \mathrm{C}$ and $100 \%$ relative humidity) for 28 days.

The compressive strength (CS) experiments were performed on a universal mechanical testing machine (SHIMADZU, model AG-IS) with a loading speed of $0.25 \pm 0.05 \mathrm{MPa} / \mathrm{s}$. The flexural strength (FS) experiments were performed on a universal mechanical testing machine (Shimadzu, model Autograph AG-X $50 \mathrm{kN}$ ), with $5 \mathrm{KN}$ load cells, the distance between the support 
points of $30 \mathrm{~mm}$, and a test speed of $0.5 \mathrm{~mm} \cdot \mathrm{min}^{-1}$. CS and FS values were obtained from the average of five specimens. Mercury intrusion porosimetry tests were performed (Auto Pore IV, model 9500-Micromeritics) with the measurement of pores in the range of $100-0.005 \mu \mathrm{m}$, under an evacuation pressure of $50 \mu \mathrm{mHg}$ for 5 minutes and intrusion pressure of $0.0034 \mathrm{MPa}$.

After 28 days of curing, a samples group was subjected to wetting and drying cycles to assess the behavior of the mortar under daily weather conditions. The alternation cycles were 24 hours at a temperature of $65^{\circ} \mathrm{C}$ and 24 hours of immersion in water. Flexural and compression strength tests were carried out after 0, 5, 10, 15, and 25 cycles.

\subsection{Resistance to alkali-aggregate reaction}

The evaluation of the alkali-aggregate reaction was performed on mortar bars followed the ASTM C1260 ("ASTM C1260-21, Standard Test Method for Potential Alkaline Reactivity of Aggregates (Mortar-Bar Method),” 2021) standard. For molding the mortar bars, used cement/aggregate proportion of 1:2.25 and water/cement ratio of 0.47 . The experiments were carried out in prismatic test specimens with $25 \mathrm{~mm} \times 25 \mathrm{~mm} \times 285 \mathrm{~mm}$. After 24 hours, the bars were unmolded, and the first measurement was recorded with a digital caliper. Then, the bars were placed in a container for curing in a $\mathrm{NaOH}$ solution, where they were kept the $80 \pm 2{ }^{\circ} \mathrm{C}$ for 30 days. Linear expansion measurements were carried out every 2 days, totaling 15 readings. After 30 days, the samples were characterized by scanning electron microscopy (SEM) coupled with the Energy Dispersive equipment (EDS). The samples were covered with carbon.

\section{Results and Discussion}

\subsection{Characterization of scheelite tailings}

Figure 1 and Table 1 show the particle size distribution of ST and sand and the physical properties of ST, respectively. The physical properties of ST presented are similar to conventional aggregate (sand) (Barros et al., 2016). According to the particle size distribution of ST, the sample had a maximum characteristic diameter of $2.4 \mathrm{~mm}$ and a fineness modulus of $2.93 \%$, being classified as coarse sand. The unit mass is in the range of $1 \leq \mathrm{\gamma} \leq 3 \mathrm{~g} / \mathrm{cm}^{3}$ and is classified as normal aggregate. It can be used as an aggregate for the production of mortar and concrete.

Figure 1. Particle size distribution of the scheelite tailings and sand.

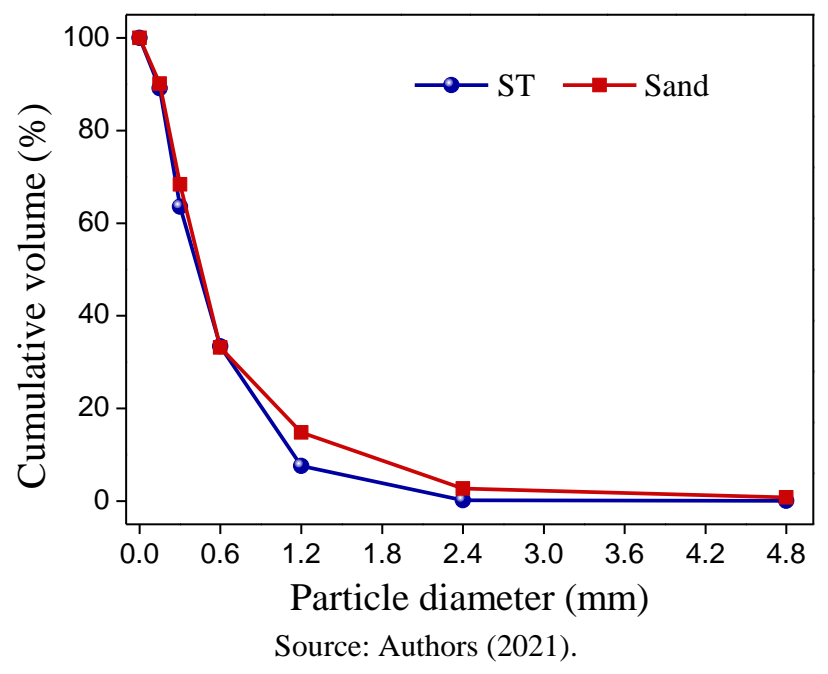


Table 1. Physical properties of the scheelite tailings and sand.

\begin{tabular}{ccc}
\hline \multirow{2}{*}{ Physical properties } & \multicolumn{2}{c}{ Values } \\
\cline { 2 - 3 } & Scheelite tailings & Sand \\
\hline Unitary mass $\left(\mathrm{g} / \mathrm{cm}^{3}\right)$ & 1.67 & 1.46 \\
Absolute specific mass $\left(\mathrm{g} / \mathrm{cm}^{3}\right)$ & 2.90 & 2.60 \\
Fineness modulus $(\%)$ & 2.93 & 2.89 \\
\hline
\end{tabular}

Source: Authors (2021).

Table 2 and Figure 2 show the chemical composition, the SEM images, and XRD patterns of the scheelite tailings. The ST consists mainly of calcium oxide $(\mathrm{CaO}>47 \%)$, from calcite, and silicon $\left(\mathrm{SiO}_{2}>26 \%\right)$, from quartz. The alumina $\left(\mathrm{Al}_{2} \mathrm{O}_{3}\right)$ content was higher than 9\%, compositions similar to those found by by (Medeiros et al., 2021). The mineralogical phases identified in the XRD patterns were the following: quartz (JCPDS 46-1045), calcite (JCPDS 72-1937), mica (JCPDS 83- 1808), and feldspar (JCPDS 09-0465). In Figure 2, it can be seen that the morphology of the scheelite tailings grains presents rounded edges with some angular faces and laminar structure. ST grains are of varying sizes, and this can be attributed to different minerals. Studies by Yin et al. (Yin et al., 2020) indicated that scheelite tailings grains had laminar and cubic morphologies, grains with different shapes, well-defined edges, and a more porous surface than normal sand.

Table 2. Chemical composition (wt $\%$ ) of scheelite tailings.

\begin{tabular}{ccccccc}
\hline Material & $\mathbf{C a O}$ & $\mathbf{S i O}_{\mathbf{2}}$ & $\mathbf{A l}_{\mathbf{2}} \mathbf{O}_{\mathbf{3}}$ & $\mathbf{F e}_{2} \mathbf{O}_{3}$ & $\mathbf{M g O}$ & Others \\
\hline $\mathrm{ST}(\%)$ & 47.30 & 31.82 & 9.75 & 6.57 & 2.46 & 2.08 \\
\hline
\end{tabular}

Source: Authors (2021).

Figure 2. SEM images and diffractograms, measured from scheelite tailings. M- Mica; Q- Quartz; F- Feldspar; Ca- Calcite.
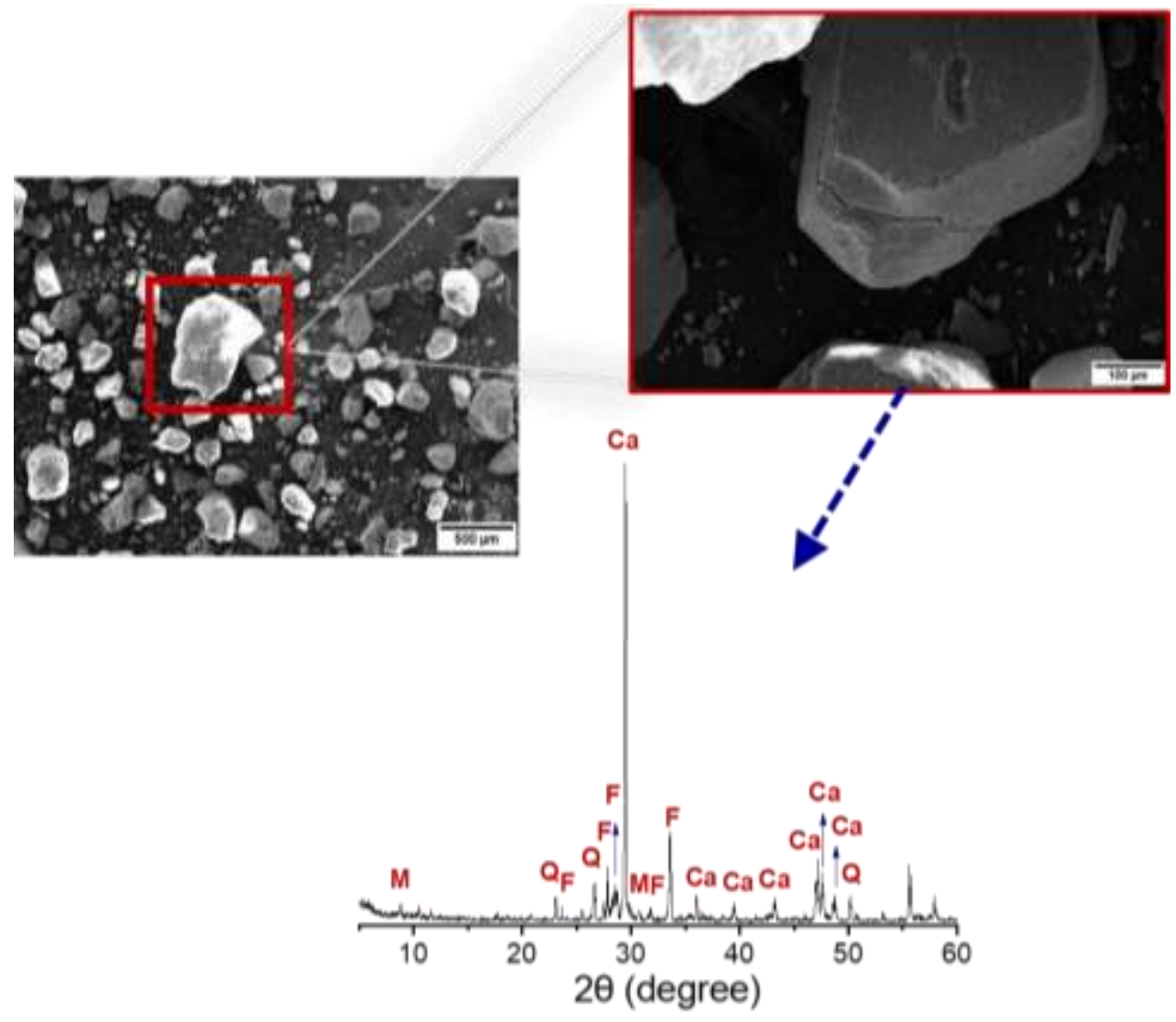

Source: Authors (2021). 


\subsection{Characterization of mortar samples}

Figure 3a-b shows the capillary water absorption values measured at 10 and $90 \mathrm{~min}$ and the porosimetry of the mortars with sand ( $0 \%$ replacement) and with the scheelite tailings (100\% replacement). In Figure 3a, it can be seen that the mortars with scheelite tailing presented higher absorption values than the samples with sand. In $10 \mathrm{~min}$, the mortar with scheelite reached 0.14 $\mathrm{g} / \mathrm{cm}^{2}$ and in $90 \min 0.36 \mathrm{~g} / \mathrm{cm}^{2}$, while the mortar with sand reached 0.11 and $0.31 \mathrm{~g} / \mathrm{cm}^{2}$ of absorption in 10 and $90 \mathrm{~min}$, respectively. The slightly higher mortar values with ST are due to the greater porosity (30.43\%) than the mortar with normal sand $(22.98 \%)$, as shown in Figure 3b.

Figure 3. Capillary absorption measured at 10 and 90 minutes (a) and accumulated porosimetry value in the mortar with sand (0\% replacement) and with the scheelite tailings (100\% replacement) (b).
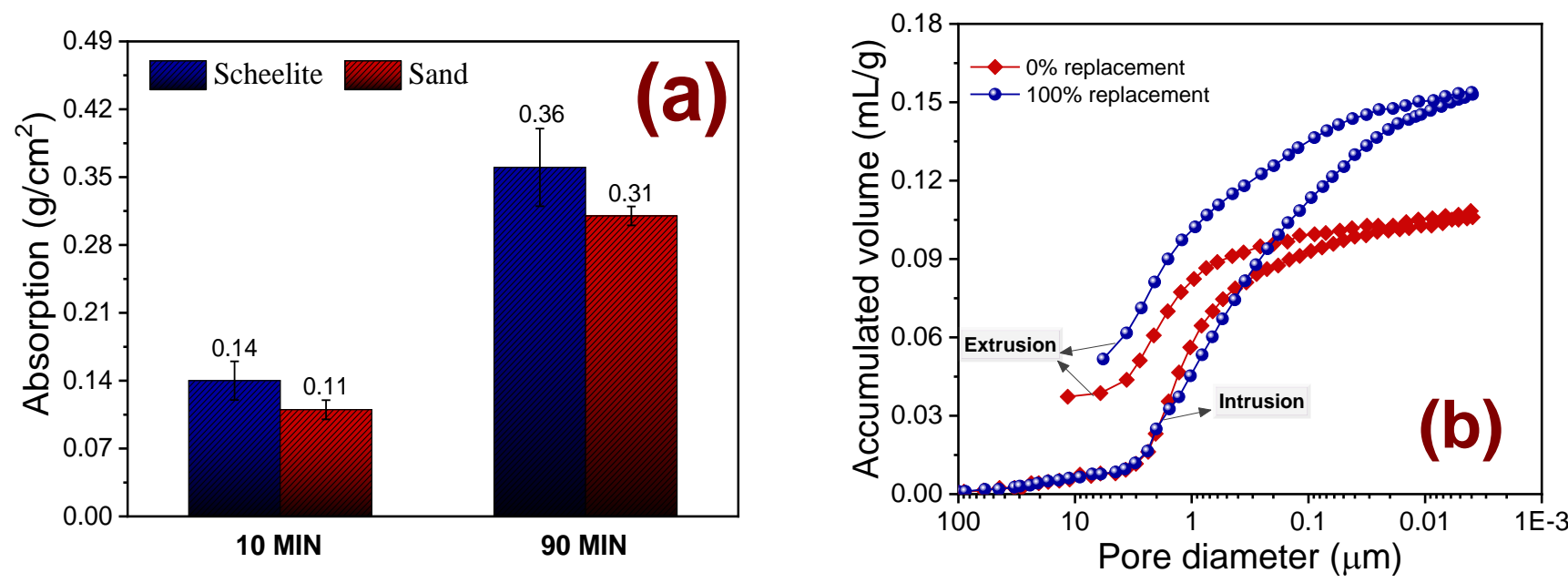

Source: Authors (2021).

Figure 4a-b shows flexural and compressive strengths of the mortar samples with scheelite tailings before (at 7 and 28 cure days, Figure 4a) and after (Figure 4b) the wetting and drying cycles. In Figure 4a, it can be observed that flexural and compressive strengths showed little variation between 7 and 28 cure days. In addition, the values of compressive strength at 28 days (3.02 MPa) are higher than the minimum 2.4 MPa required by the ASTM C270 standard ("ASTM C270-19ae1, Standard Specification for Mortar for Unit Masonry," 2019). In Figure 4b, it is clear that there was no loss in mechanical performance after the mortars were subjected to wetting and drying cycles. A significant increase in mechanical strength was observed up to the 5th cycle; after that, there were no significant variations in mechanical strength values. 
Figure 4. Flexural and compressive strength of the mortar samples at 7 and 28 cure days (a) and mechanical performance after wetting and drying cycles $(\mathbf{b})$.
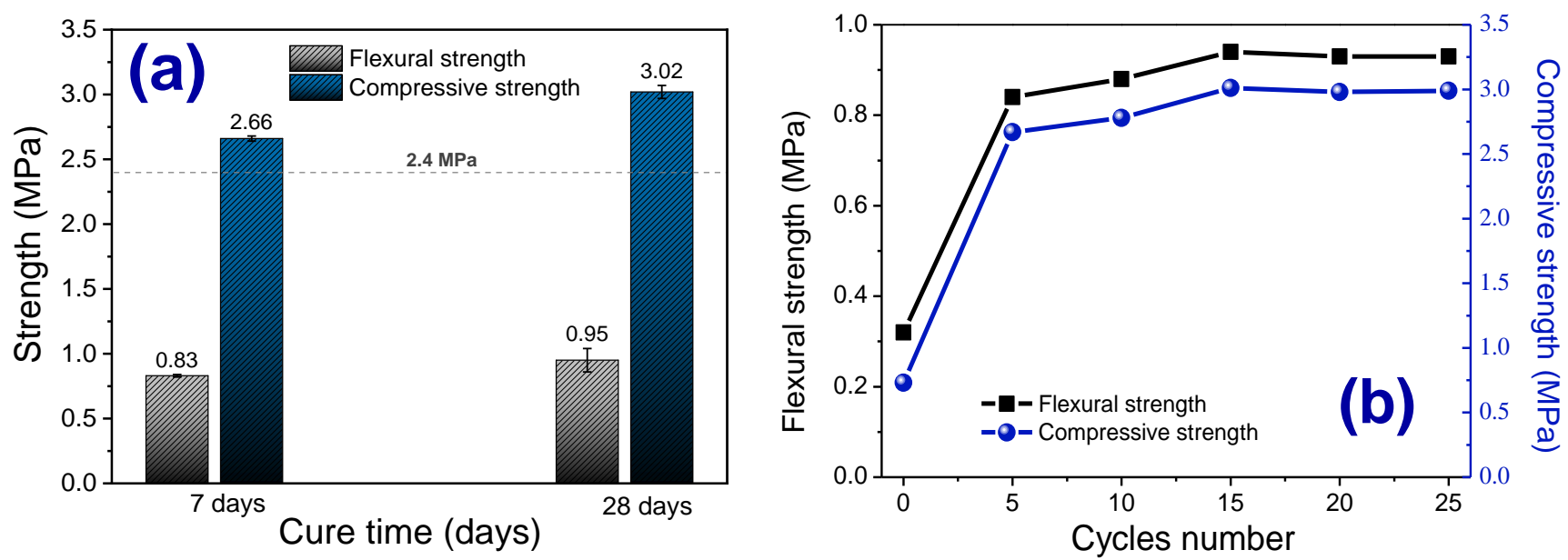

Source: Authors (2021).

\subsection{Alkali-Aggregate Reaction (AAR)}

Figure 5 shows the values of the alkali-aggregate reaction of the mortars incorporated with scheelite tailings. The test showed that up to the 16th day, the specimens presented expansion below $0.08 \%$, located in the innocuous expansion region. Only from the $22^{\circ}$ day did the material show potential expansion. On the $28^{\circ}$ day of testing, the expansion was deleterious, reflecting a tendency to reactivity at the end of the process. According to ASTM C 1260 ("ASTM C1260-21, Standard Test Method for Potential Alkaline Reactivity of Aggregates (Mortar-Bar Method)", 2021), the aggregate is considered reactive to the alkali-aggregate reaction if the expansion is greater than $0.10 \%$ and $0.20 \%$ after 14 and 28 days, respectively. The mortar with scheelite tailings showed expansion values below $0.10 \%$ in 14 days $(0.08 \%)$. Thus, the material under study has a strong potential to be used as a substitute for sand for the production of mortars. However, at 28 days, the expansion values $(0.21 \%)$ surpassed the maximum value of 0.20\% established by ASTM C 1260 ("ASTM C1260-21, Standard Test Method for Potential Alkaline Reactivity of Aggregates (Mortar-Bar Method)", 2021). Therefore, the mortar samples with ST aggregate had their microstructure evaluated to verify if the deleterious expansion that occurred at 28 days is related to the formation of the amorphous alkaline gel, characteristic of the alkali-aggregate reaction. It is well known that an amorphous alkaline gel can be formed due to the alkali-aggregate reaction. This gel is highly expansive and can cause micro-cracks and cracks in the material. Some authors (Evaristo De Oliveira Neto et al., 2021; Munhoz et al., 2021) have identified the presence of this amorphous alkaline gel via microstructure analysis.

The microstructure of the samples was investigated from SEM images and mapping by EDS in the regions where cracks and microcracks occurred. It is well known that an amorphous gel can be formed as a consequence of the alkali-aggregate reaction. It is known that the $\mathrm{OH}^{-}$contained in the mortar's pores (from immersion in the aggressive environment of $\mathrm{NaOH}$ ) comes into contact with the mortar's reactive minerals. These, in turn, can react with alkalis present in Portland cement, originating the alkali-silicate reaction (Evaristo De Oliveira Neto et al., 2021). Figure 6 shows the image obtained by Scanning Electron Microscopy using backscattered electrons (SEM-BSE), in which it was possible to identify the pores of the samples, the aggregates (Scheelite tailings), and the hydration products of the cement paste, such as calcium hydroxide (C-H), hydrated calcium silicate (C-S-H), identified in the circled regions of the image. From Figure 6 is possible to notice no amorphous alkaline gel formation inside the pores, as observed in other works (Barreto Santos et al., 2021; Munhoz et al., 2021; Rashidian-Dezfouli \& Rangaraju, 2021). 
Figure 5. Linear expansions measured from the samples immersed in the aqueous solution of $\mathrm{NaOH}$ by 30 days.

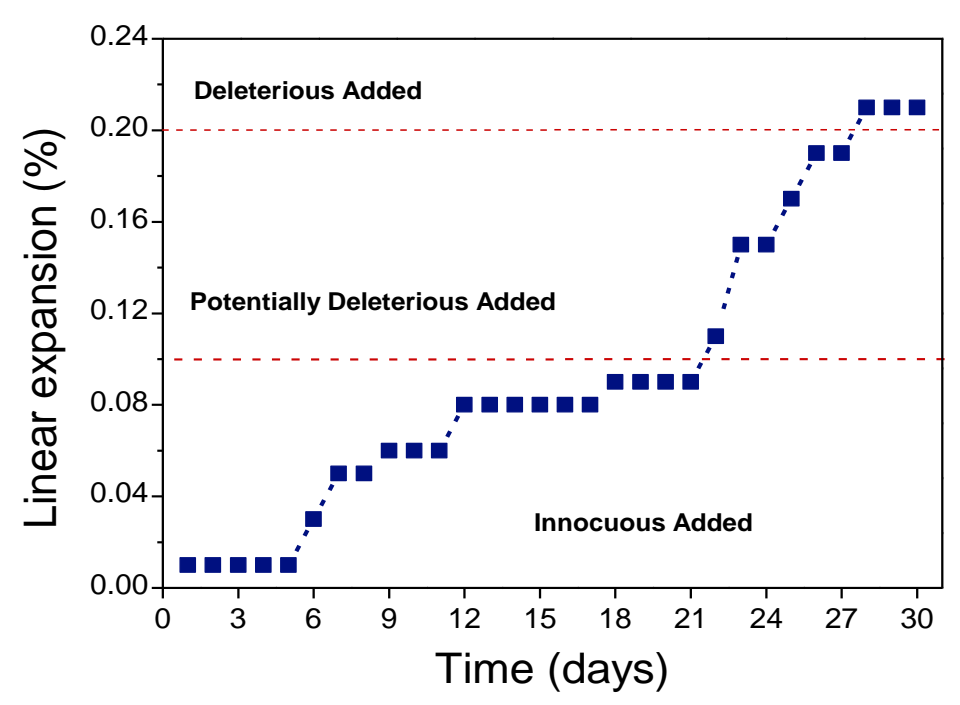

Source: Authors (2021).

Figure 6. SEM of mortar sample with calcium hydroxide crystals $(\mathrm{C}-\mathrm{H})$ and the identification of voids without the presence of deleterious gels.

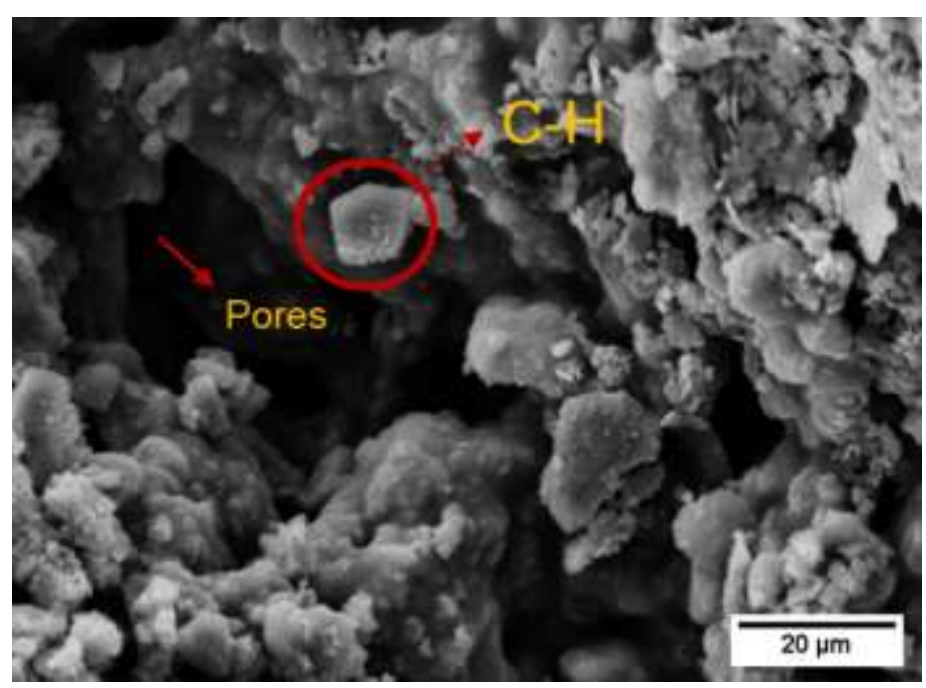

Source: Authors (2021).

In some images obtained by mirrored electrons of polished samples, some cracks that could be due to a deleterious expansive process were identified. According to Leeman (Leemann, 2017), the presence of silica, calcium, and alkalis are present in AAR products, so the chemical composition of each crack was analyzed by EDS to verify the presence of these elements in the crack regions. Figure 7 illustrates a crack that covers the region of the mortar incorporated with scheelite tailings. The mapping of this region showed the presence of silica only in the aggregate particles. In the crack, there is no presence of silica, exempting the formation of ASR in this delimited region. 
Figure 7. SEM of mortar sample with calcium hydroxide crystals $(\mathrm{C}-\mathrm{H})$ and the identification of voids without the presence of deleterious gels.

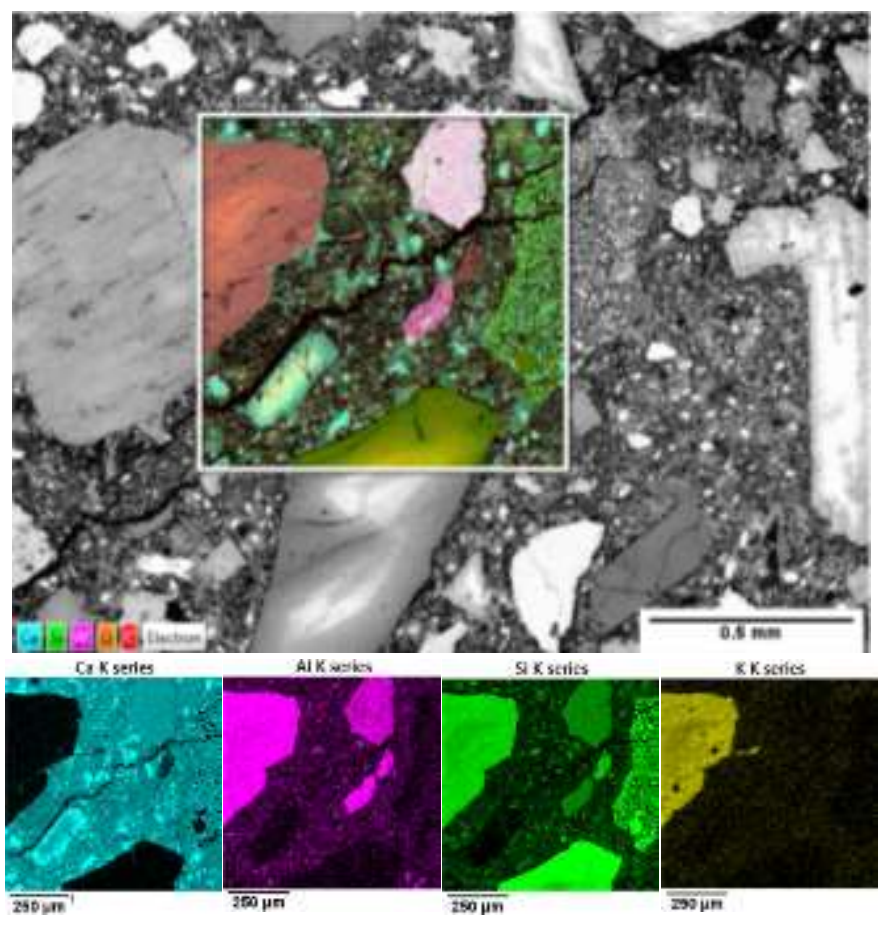

\begin{tabular}{cc}
\hline Elem. & $\mathrm{Wt} \%$ \\
\hline $\mathrm{Ca}$ & 45.0 \\
$\mathrm{Si}$ & 36.1 \\
$\mathrm{Al}$ & 6.8 \\
$\mathrm{Na}$ & 5.3 \\
$\mathrm{~K}$ & 4.4 \\
$\mathrm{Fe}$ & 2.4 \\
\hline
\end{tabular}

Source: Authors (2021).

\section{Conclusion}

Sustainable mortars were produced with scheelite tailings in total replacement to natural sand aggregate. The results of the chemical characterization showed that the scheelite tailings have chemical and physical characteristics similar to those of natural sand. The durability tests after wetting and drying cycles showed no variation in the mechanical performance of the mortar with tailings, even after 25 cycles. The expansion test in mortar bars showed values $<0.10 \%$ in 14 days $(0.08 \%)$. However, at 28 days, the expansion values ( $0.21 \%$ ) exceeded the maximum value of $0.20 \%$ established by ASTM C 1260 .

The microstructural analysis (SEM and EDS) performed in the pores and cracks of the mortars did not show evidence of the formation of the alkaline gel characteristic of the alkali-aggregate reaction. This indicates that the deleterious expansion at 28 days is not related to the alkali-aggregate reaction. Mechanical tests indicate that the replacement of sand with scheelite tailings for the production of mortar is satisfactory. However, more advanced studies are needed to justify the deleterious expansion after 28 days and the long-term durability behavior.

\section{References}

Alekseev, K., Mymrin, V., Avanci, M. A., Klitzke, W., Magalhães, W. L. E., Silva, P. R., Catai, R. E., Silva, D. A., \& Ferraz, F. A. (2019). Environmentally clean construction materials from hazardous bauxite waste red mud and spent foundry sand. Construction and Building Materials, 229, 116860. https://doi.org/10.1016/j.conbuildmat.2019.116860.

Almeida, E. P., Carreiro, M. E. A., Rodrigues, A. M., Ferreira, H. S., Santana, L. N. L., Menezes, R. R., \& Neves, G. A. (2021). A new eco-friendly mass formulation based on industrial mining residues for the manufacture of ceramic tiles. Ceramics International, 47(8), 11340-11348. https://doi.org/10.1016/j.ceramint.2020.12.260.

ASTM C1260-21, Standard test method for potential alkaline reactivity of aggregates (mortar-bar method). (2021). ASTM International, West Conshohocken, $P A$. https://doi.org/10.1520/C1260-21.

ASTM C128-15, Standard Test Method for Relative Density (Specific Gravity) and Absorption of Fine Aggregate. (2015). ASTM International, West Conshohocken, PA. https://doi.org/10.1520/C0128-15.

ASTM C1437-20, Standard Test Method for Flow of Hydraulic Cement Mortar. (2020). ASTM International, West Conshohocken, PA. 
https://doi.org/10.1520/C1437-20.

ASTM C270-19ae1, Standard Specification for Mortar for Unit Masonry. (2019). ASTM International, West Conshohocken, PA. https://doi.org/10.1520/C027019AE01.

ASTM C29 / C29M-17a, Standard Test Method for Bulk Density ("Unit Weight”) and Voids in Aggregate. (2017). ASTM International, West Conshohocken. https://doi.org/10.1520/C0029_C0029M-17.

Barreto Santos, M., de Brito, J., Santos Silva, A., \& Hawreen, A. (2021). Evaluation of alkali-silica reaction in recycled aggregates: The applicability of the mortar bar test. Construction and Building Materials, 299, 124250. https://doi.org/10.1016/J.CONBUILDMAT.2021.124250.

Barros, S. V. A., Marciano, J. E. A., Ferreira, H. C., Menezes, R. R., \& Neves, G. D. A. (2016). Addition of quartzite residues on mortars: Analysis of the alkali aggregate reaction and the mechanical behavior. In Construction and Building Materials. 118, 344-351. https://doi.org/10.1016/j.conbuildmat.2016.05.079.

Choi, Y. C., \& Choi, S. (2015). Alkali-silica reactivity of cementitious materials using ferro-nickel slag fine aggregates produced in different cooling conditions. Construction and Building Materials, 99, 279-287. https://doi.org/10.1016/J.CONBUILDMAT.2015.09.039.

Coppio, G. J. L., de Lima, M. G., Lencioni, J. W., Cividanes, L. S., Dyer, P. P. O. L., \& Silva, S. A. (2019). Surface electrical resistivity and compressive strength of concrete with the use of waste foundry sand as aggregate. Construction and Building Materials, 212 , 514-521. https://doi.org/10.1016/J.CONBUILDMAT.2019.03.297.

De Grazia, M. T., Goshayeshi, N., Gorga, R., Sanchez, L. F. M., Santos, A. C., \& Souza, D. J. (2021). Comprehensive semi-empirical approach to describe alkali aggregate reaction (AAR) induced expansion in the laboratory. Journal of Building Engineering, 40, 102298. https://doi.org/10.1016/J.JOBE.2021.102298.

Evaristo De Oliveira Neto, R., De Melo Cartaxo, J., Mendes Rodrigues, A., De Araújo Neves, G., Rodrigues Menezes, R., Pereira Da Costa, F., Valensca, S., \& Barros, A. (2021). Durability Behavior of Mortars Containing Perlite Tailings: Alkali-Silicate Reaction Viewpoint. https://doi.org/10.3390/su13169203.

Fernandes, J. V., Guedes, D. G., da Costa, F. P., Rodrigues, A. M., Neves, G. de A., Menezes, R. R., \& Santana, L. N. de L. (2020). Sustainable Ceramic Materials Manufactured from Ceramic Formulations Containing Quartzite and Scheelite Tailings. Sustainability, 12(22), 9417. https://doi.org/10.3390/su12229417.

Figueirêdo, J. M. R. de, Costa, F. P. da, Fernandes, J. V., Rodrigues, A. M., Neves, G. de A., Menezes, R. R., \& Santana, L. N. de L. (2020). Development of Scheelite Tailings-Based Ceramic Formulations with the Potential to Manufacture Porcelain Tiles, Semi-Stoneware and Stoneware. Materials, 13(22), 5122. https://doi.org/10.3390/ma13225122.

Furberg, A., Arvidsson, R., \& Molander, S. (2019). Environmental life cycle assessment of cemented carbide (WC-Co) production. Journal of Cleaner Production, 209, 1126-1138. https://doi.org/10.1016/J.JCLEPRO.2018.10.272.

Hoppe Filho, J., Pires, C. A. O., Leite, O. D., Garcez, M. R., \& Medeiros, M. H. F. (2021). Red ceramic waste as supplementary cementitious material: Microstructure and mechanical properties. Construction and Building Materials, 296, 123653. https://doi.org/10.1016/J.CONBUILDMAT.2021.123653.

Huseien, G. F., Sam, A. R. M., Mirza, J., Tahir, M. M., Asaad, M. A., Ismail, M., \& Shah, K. W. (2018). Waste ceramic powder incorporated alkali activated mortars exposed to elevated Temperatures: Performance evaluation. Construction and Building Materials, 187, 307-317. https://doi.org/10.1016/J.CONBUILDMAT.2018.07.226

Leemann, A. (2017). Raman microscopy of alkali-silica reaction (ASR) products formed in concrete. Cement and Concrete Research, 102, 41-47. https://doi.org/10.1016/J.CEMCONRES.2017.08.014.

Matias, G., Torres, I., Rei, F., \& Gomes, F. (2020). Analysis of the functional performance of different mortars with incorporated residues. Journal of Building Engineering, 29, 101150. https://doi.org/10.1016/J.JOBE.2019.101150.

Medeiros, A. G., Gurgel, M. T., da Silva, W. G., de Oliveira, M. P., Ferreira, R. L. S., \& de Lima, F. J. N. (2021). Evaluation of the mechanical and durability properties of eco-efficient concretes produced with porcelain polishing and scheelite wastes. Construction and Building Materials, 296, 123719. https://doi.org/10.1016/J.CONBUILDMAT.2021.123719.

Munhoz, G. S., Dobrovolski, M. E. G., Pereira, E., \& Medeiros-Junior, R. A. (2021). Effect of improved autogenous mortar self-healing in the alkali-aggregate reaction. Cement and Concrete Composites, 117, 103905. https://doi.org/10.1016/J.CEMCONCOMP.2020.103905.

Pereira-De-Oliveira, L. A., Castro-Gomes, J. P., \& Santos, P. M. S. (2012). The potential pozzolanic activity of glass and red-clay ceramic waste as cement mortars components. Construction and Building Materials, 31, 197-203. https://doi.org/10.1016/J.CONBUILDMAT.2011.12.110.

Rashidian-Dezfouli, H., \& Rangaraju, P. R. (2021). Study on the effect of selected parameters on the alkali-silica reaction of aggregate in ground glass fiber and fly ash-based geopolymer mortars. Construction and Building Materials, 271, 121549. https://doi.org/10.1016/J.CONBUILDMAT.2020.121549.

Samadi, M., Huseien, G. F., Mohammadhosseini, H., Lee, H. S., Abdul Shukor Lim, N. H., Tahir, M. M., \& Alyousef, R. (2020). Waste ceramic as low cost and eco-friendly materials in the production of sustainable mortars. Journal of Cleaner Production, 266, 121825. https://doi.org/10.1016/J.JCLEPRO.2020.121825.

Souza, M. M., Anjos, M. A. S., \& Sá, M. V. V. A. (2021). Using scheelite residue and rice husk ash to manufacture lightweight aggregates. Construction and Building Materials, 270, 121845. https://doi.org/10.1016/J.CONBUILDMAT.2020.121845.

Torres, I., Matias, G., \& Faria, P. (2020). Natural hydraulic lime mortars - The effect of ceramic residues on physical and mechanical behaviour. Journal of Building Engineering, 32, 101747. https://doi.org/10.1016/J.JOBE.2020.101747.

Yin, C., Ji, L., Chen, X., Liu, X., \& Zhao, Z. (2020). Efficient leaching of scheelite in sulfuric acid and hydrogen peroxide solution. Hydrometallurgy, 192, 105292. https://doi.org/10.1016/J.HYDROMET.2020.105292. 